\author{
Лейла Султанова, \\ доктор педагогічних наук, \\ старший науковий співробітник, \\ професор кафедри професійної та вищої освіти, \\ Центральний інститут післядипломної освіти ДВНЗ \\ «Університет менеджменту освіти» \\ (м. Київ, Україна) \\ Leila Sultanova, \\ Doctor of Pedagogical Sciences, \\ Senior Researcher, \\ Professor of the Department of Vocational \\ and Higher Education, \\ University of Educational Management \\ (Kyiv, Ukraine) \\ leilasultanova22.07@gmail.com \\ ORCID ID 0000-0002-3324-6926
}

\title{
ЦІННІСНІ ОРІЕНТАЦІЇ МАЙБУТНЬОГО ВИКЛАДАЧА ЗАКЛАДУ ВИЩОЇ ОСВІТИ
}

Анотація. У статті обґрунтовано актуальність проблеми ціннісних орієнтацій майбутнього викладача закладу вищої освіти. Визначено сутність понять «цінності» та «ціннісні орієнтації». 3'ясовано, що цінності складають основу ціннісних орієнтацій індивіда. У науковій літературі розрізняють матеріальні, суспільно-політичні, духовні цінності; позитивні і негативні цінності; цінності особистості, соціальних та професійних груп, національні, загальнолюдські цінності. Серед цінностей людського буття і культури при всьому розмаїтті найчастіше виділяють лише декілька, як правило, основних: людина, життя, добро, краса, істина, свобода тощо. Розкрито психолого-педагогічний аспект ціннісних орієнтацій.

У публікації наголошується на тому, що дослідження передбачає лише вивчення змісту ціннісних орієнтацій майбутнього викладача закладу вищої освіти, але не виключається можливість змін у системі ціннісних орієнтацій майбутнього викладача під впливом організованого нами процесу формування та розвитку полікультурної компетентності.

Описано методику визначення рівня ціннісних орієнтацій. Для цього використано методику «Ціннісні орієнтації» Мілтона Рокича (Milton Rokeach), який розрізняє два класи цінностей: термінальні та інструментальні. Здійснений якісний і кількісний аналіз системи ціннісних орієнтацій майбутнього викладача до та після реалізації чотирьох етапів формування полікультурної компетентності засвідчив ефективність розробленого та запропонованого нами змісту полікультурної освіти.

Ключові слова: цінності, ціннісні орієнтації, майбутній викладач, викладач закладу вищої освіти, полікультурне суспільство.

\section{VALUE ORIENTATIONS OF THE FUTURE TEACHER OF HIGHER EDUCATION INSTITUTION}

\begin{abstract}
The article substantiates the urgency of the problem of value orientations of the future teacher of higher education institution. The essence of the concepts of "values" and "value orientations" is defined. Values have been found to form the basis of an individual's value orientations. It is distinguished material, socio-political, spiritual values; positive and negative values; values of personality, social and professional groups, national, universal values in the scientific literature. Among the values of human being and culture, in spite of the great variety only some values appear more frequent, as a rule, basic ones: man, life, good, beauty, truth, freedom, etc. In our publication we place emphasis on the value orientations of the future teacher as one of the components of multicultural competence. This is primarily the value orientations of the individual, which act as social determinants of behavior in a multicultural society.

The psychological-pedagogical aspect of value orientations is revealed from two positions: research of value orientations as a component of process of a human development and also as a certain result of personal development.

The publication emphasizes that the research provides only the study of the content of the value orientations of the future teacher of higher education institution, but does not exclude the possibility of changes in the system of value orientations of the future teacher under the influence of the process of formation and development of multicultural competence organized by us.

The method of determining the level of value orientations is described. For this, it was used Milton Rokeach's technique «Value Orientation» who distinguishes two classes of values: terminal and instrumental. Conducted the qualitative and quantitative analysis of the future teacher's system of value orientations before and after the implementation of the four stages of formation of multicultural competence proved the effectiveness of the developed and proposed content of multicultural education.
\end{abstract}

Keywords: values, value orientations, future teacher, teacher of higher education institution, multicultural society. 


\section{ВСТУП}

Постановка проблеми. Сучасна суспільна свідомість все більше утверджується в думці про те, що людство переживає різкі зміни. Тому аксіологічний підхід є одним з базових у вивченні проблеми полікультурної освіти майбутніх викладачів. Про це свідчать масштабні катаклізми сучасного суспільства, під час яких проявилися жорстокість, деформація гуманістичних цінностей, соціальний, моральний, економічний та інтелектуальний хаос. Ці явища $€$ проявом культурної кризи та відображенням глибинних станів людини. Зміна соціальноекономічних шляхів розвитку суспільства поставила під сумнів колишню систему цінностей, що, зі свого боку, стало причиною переходу культури з одного стійкого стану в інший, який тільки передбачається, при якому людина випадає з однієї системи цінностей і намагається утвердитися в іншій.

Гуманітарні цінності $€$ інтегрувальною основою будь-якої соціальної спільноти. Наявність цілісної системи цінностей у суспільстві забезпечує стабільність усіх сфер його життя, а її розпад неминуче веде до дисгармонії, руйнівних конфліктів у суспільстві. Значення цінностей як для окремого соціуму, так і для всього людства особливо зростає на зламі епох, коли йде пошук нових орієнтирів розвитку. Саме тому проблема ціннісних орієнтацій майбутнього викладача закладу вищої освіти набуває сьогодні особливої актуальності.

Аналіз наукових досліджень і публікацій. Окремі аспекти проблеми формування ціннісних орієнтацій майбутнього викладача закладу вищої освіти висвітлені у низці наукових досліджень останніх років. Зокрема, зарубіжний досвід з означеної проблеми представлено у публікаціях Андрущенко В. (2013); сутність понять «цінності» та «ціннісні орієнтації» проаналізована науковцями Удич О. (2014), Хомич Л. (2010); вплив середовища на ціннісні орієнтації майбутніх фахівців досліджувала Барановська Л. (2017); проблема формування ціннісних орієнтацій висвітлена в публікаціях Баранівського В. (2014), Онофрійчук Л. (2011), Печерської Г. (2013), Щепової Д. (2010).

\section{МЕТА І ЗАВДАННЯ ДОСЛІДЖЕННЯ}

Мета дослідження полягає у визначенні сутності ціннісних орієнтацій, аналізі ціннісних орієнтацій особистості майбутнього викладача як одного 3 компонентів полікультурної компетентності, у розкритті психологопедагогічного аспекту ціннісних орієнтацій, здійсненні якісного і кількісного аналізу системи ціннісних орієнтацій майбутнього викладача до та після реалізації чотирьох етапів формування полікультурної компетентності.

\section{МЕТОДИ ДОСЛІДЖЕННЯ:}

- загальнонаукові - аналіз, синтез, порівняння, систематизація та узагальнення для вивчення праць зарубіжних та вітчизняних науковців;

- конкретнонаукові - інтерпретації для визначення базових понять дослідження;

- емпіричні - тестування для виявлення рівня ціннісних орієнтацій.

\section{РЕЗУЛЬТАТИ ДОСЛІДЖЕННЯ}

Цінність - це термін, який використовують у філософії та соціології для позначення позитивного чи негативного значення об'єктів навколишнього світу для людини, соціальної групи, суспільства в цілому, яке визначається власне їхніми ознаками та їхнім впливом на сферу людської життєдіяльності, інтересів і потреб, соціальних відносин. Критерії та способи оцінки цієї значущості виражені у моральних принципах і нормах, ідеалах, установках, цілях (Новейший философский словарь, 1998, с. 798.). У структурі особистості цінності представлені через ціннісні орієнтації. Хоча ціннісні орієнтації становлять надзвичайно важливий компонент структури особистості, проте аналіз цілої низки робіт свідчить про відсутність єдності у визначенні їх суті. Це зумовлено наявністю різних дослідницьких підходів, а також складністю самого феномену, яка полягає в тому, що ціннісні орієнтації пов'язані з такими особистісними утвореннями, як мотиви, інтереси, стосунки тощо.

Ціннісні орієнтації - елементи внутрішньої (диспозиційної) структури особистості, які сформовано та закріплено життєвим досвідом індивіда у процесах соціалізації та соціальної адаптації, коли відокремлюється те, що має значення (суттєве для конкретної людини), від того, що не має важливого значення (несуттєвого), через прийняття або неприйняття особистістю певних цінностей, усвідомлюваних як межі (горизонти) граничних смислів й основоположних цілей життя, а також визначаються припустимі засоби їхньої реалізації (Новейший философский словарь, 1998, с. 798.).

У структурі особистості ціннісні орієнтації утворюють вищий (як правило, усвідомлюваний - на відміну від соціальних установок) рівень ієрархії схильностей до певного сприйняття умов життєдіяльності, їхньої оцінки і поведінки як в актуальній (тут і тепер), так i, перш за все, у довгостроковій перспективі. Таке розуміння змісту поняття відповідає початковому значенню слова «орієнтація» (від лат. oriens, orientis - схід), що тлумачать як просторове розташування відповідно до сходу, у домінантний спосіб визначеної точки сходу сонця, - але такому, що переноситься у простір смисловий, а через нього - у соціальний. Ціннісні орієнтації відповідно визначають загальне спрямування інтересів і прагнення особистості, ієрархію індивідуальних переваг і зразків, цільовий та мотиваційний напрям тощо. Вони проявляються і розкриваються через оцінювання людиною себе, інших, обставин тощо, через уміння структурувати життєві ситуації, приймати рішення у проблемних ситуаціях і виходити з конфліктів.

Розмаїття цінностей, що складають основу ціннісних орієнтацій індивіда, передбачає потребу їхньої класифікації. Так, у науковій літературі розрізняють матеріальні, суспільно-політичні, духовні цінності; позитивні і негативні цінності; цінності особистості, соціальних та професійних груп, національні, загальнолюдські цінності. Серед цінностей людського буття і культури при всьому розмаїтті найчастіше виділяють лише декілька, як правило, основних: людина, життя, добро, краса, істина, свобода тощо.

Сьогодні особливої ваги та значення набувають загальнолюдські цінності. Вони є регуляторами поведінки всього людства, виступаючи найважливішими критеріями, стимулами та знаряддями пошуку шляхів взаєморозуміння, злагоди та збереження життя людей планети. Загальнолюдські цінності покликані об'єднати людство в єдине 
ціле, і передбачається, що їх однаково сприймають люди різних рас, епох, культур. Чим більше таких цінностей у розпорядженні народу, групи людей, тим більш упевнено вони себе почувають у житті, тим багатшим та яскравішим стає їх повсякденне життя. Проте далеко не всі цінності мають універсальний характер. Зі зміною історичних епох уявлення про цінності змінювались. У філософії ціннісний (аксіологічний) підхід передбачає з'ясування співвідношення (субординації) різних цінностей у їхньому взаємозв'язку з реальними явищами. Звідси виникає проблема абсолютизації та релятивізації (від лат. relativus - відносний - визнання відносності, умовності та суб'єктивності пізнання, заперечення абсолютних етичних норм і правил) ціннісних орієнтацій. Суть релятивізації у тому, що істинне і хибне, правильне і неправильне, добре і погане час від часу міняються місцями залежно від людей та умов. Те, що люди роблять в одній системі, є правильним для них, але не все є належним і правильним для кожної людини. Іншими словами, певній культурі властиві цінності, які не завжди прийнятні для інших культур.

у глобалізаційних процесах сучасності зіштовхуються дві системи цінностей людини: система цінностей традиційної культури і система цінностей, яка побудована згідно з ліберальними та демократичними орієнтирами. Зіткнення цих двох систем цінностей можна розглядати, з одного боку, як історичну спадковість цінностей людини, де традиційні цінності трансформуються у нові та відповідають новим світовим реаліям, тобто ліберальнодемократичні цінності. 3 іншого - як протистояння двох світів: старого традиційного і сучасного демократичного, що іноді стає причиною політичних, релігійних та воєнних конфліктів. Суперечності між традиційними і сучасними цінностями є однією з основних причин реальної відсутності цілісної системи цінностей людини. Окремі дослідники вважають, що сучасний світ втратив ціннісну основу своєї життєдяльності. Глобалізація зробила ці процеси загальними. Війни у традиційному розумінні вже не потрібні, оскільки зараз для досягнення подібного результату достатньо зруйнувати систему цінностей супротивника.

Отже, питання визначення ціннісних пріоритетів сучасного суспільства є актуальним і доволі суперечливим. Дослідження ціннісних пріоритетів, як будь-яке філософське питання, є різноаспектним.

У своїй публікації ми акцентуємо увагу на ціннісних орієнтаціях особистості майбутнього викладача як одного з компонентів полікультурної компетентності. Це, насамперед, ціннісні орієнтації особистості, які виступають у ролі соціальних детермінантів поведінки в полікультурному суспільстві.

Формування полікультурної компетентності майбутніх викладачів спрямоване на усвідомлення та внутрішнє сприйняття культурного різноманіття як однієї 3 основних загальнолюдських цінностей, переконання в рівноправності і рівноцінності культур, усвідомлення себе як людини культури. У зв'язку з тим, що предмети і явища навколишнього світу володіють низкою об'єктивних характеристик, які є підставою для їх суб'єктивної оцінки, формування полікультурної компетентності передбачає осмислення таких найвищих цінностей, як: людина, істина, свобода, справедливість, пізнання, краса та ін. Адже система цінностей майбутнього викладача є для нього певним орієнтиром в професійній діяльності, вказує на особистісне, соціально-культурне значення об'єктів і явищ, виявляє позитивне або негативне ставлення до них. Навчально-виховний процес, спрямований на полікультурну освіту, сприяє становленню системи ціннісних орієнтацій майбутнього викладача. Підтвердженням цього є і думка Лідії Хомич про те, що система цінностей педагога - це його внутрішній світ, що виникає найбільшою мірою як результат професійно-педагогічної підготовки у вищому навчальному закладі (Хомич, Л., 2014, с. 89-90).

Ціннісні орієнтації є важливим складником структури особистості викладача, оскільки система ціннісних орієнтацій особистості дозволяє встановити загальні соціальні детермінанти поведінки (причини певної моделі поведінки). У психолого-педагогічних дослідженнях ціннісні орієнтації особистості вивчають з двох позицій: з позиції виявлення передумов виникнення ціннісних орієнтацій та механізмів їх формування, тобто дослідження ціннісних орієнтацій як складника процесу розвитку особистості, а також як наслідок взаємодії суб'єктивних і об'єктивних детермінант особистісного розвитку, тобто як певний результат особистісного розвитку. Виходячи з цього, виокремлюють два підходи у вивченні ціннісних орієнтацій особистості. у першому підході основним предметом дослідження є психічні процеси, які зумовлюють формування в особистості тієї чи іншої системи цінностей і властивих їй ціннісних орієнтацій. У другому підході предметом дослідження $€$ безпосередньо зміст системи цінностей, їі ієрархічна структура, регулятивна функція в суспільній поведінці (Тюрина, В., Научитель, Е., 1998, с. 6).

Наше дослідження зорієнтоване на другий підхід і передбачає вивчення змісту ціннісних орієнтацій майбутнього викладача закладу вищої освіти.

Незважаючи на те, що ми вивчаємо лише зміст системи ціннісних орієнтацій майбутнього викладача і не передбачаємо організацію процесу формування ціннісних орієнтацій, ми не виключаємо можливості змін у системі ціннісних орієнтацій майбутнього викладача під впливом організованого нами освітнього процесу. Адже, як правильно зазначають Валентина Тюріна та Олена Научитель, система ціннісних орієнтацій не є стабільною і незмінною. Вона може змінюватись під впливом соціально-економічного, політичного та культурного середовища (Тюрина, В., Научитель, Е., 1998, с. 16).

3 метою визначення ціннісних орієнтацій майбутніх викладачів нами було обрано найбільш поширену в прикладних дослідженнях класифікацію цінностей, запропоновану Мілтоном Рокичем. Дослідження Мілтона Рокича, які проводились у кінці 60-х та в 70-х роках XX століття у США на основі розробленого ним методу прямого ранжування цінностей, науковці вважають методично найбільш обґрунтованим напрямом у дослідженнях ціннісних орієнтацій (Леонтьев, Д., 1998).

Мілтон Рокич розрізняє два класи цінностей: термінальні та інструментальні. Під термінальними цінностями автор розуміє переконання в тому, що якась кінцева мета індивідуального існування з особистого і суспільного поглядів заслуговує на те, щоб до неї прагнути; під інструментальними цінностями - переконання в тому, що певний образ дій (наприклад, чесність, раціоналізм) з особистого і суспільного поглядів є більш доречним у будь-яких ситуаціях. 
Для діагностики індивідуальних ієрархій цінностей Мілтон Рокич розробив метод прямого ранжування цінностей, згрупованих у два списки, - термінальних та інструментальних цінностей. Цей поділ відповідає традиційному поділу на цінності-цілі (18 цінностей) і цінності-засоби (18 цінностей).

Дмитро Леонтьєв зазначає, що масштабні дослідження, проведені Мілтоном Рокичем за допомогою цього методу на загальнонаціональній американській вибірці, дозволили виявити і проаналізувати зв'язок декларованої значущості (рангу) різних цінностей з такими змінними, як стать, вік, соціальний стан, дохід, освіта, расова приналежність, політичні переконання. Результати дослідження інших авторів показали зв'язок цінностей з деякими особистісними особливостями, а також їх кроскультурну специфіку (Леонтьев, Д., 1998).

Нами було здійснено якісний і кількісний аналіз системи ціннісних орієнтацій майбутнього викладача. 3 метою визначення ціннісних орієнтацій майбутнього викладача, респондентам було запропоновано проранжувати список із 36 цінностей (по 18 цінностей у кожному списку). Завдання полягало у тому, щоб розкласти їх за порядком значущості принципів, якими респондент керується у своєму житті. Таким чином, найбільш значуща цінність буде на першому місці, а найменш важлива - на останньому (вісімнадцятому).

Із запропонованого списку нами аналізувалось ранжування лише тих цінностей, які, на наш погляд, мають значення для ефективної міжкультурної взаємодії. Це такі термінальні цінності, як: життєва мудрість; краса природи і мистецтва (переживання прекрасного в природі і в мистецтві); пізнання (можливість розширення свого кругозору, загального рівня культури, освіти, інтелектуальний розвиток); розвиток (робота над собою, постійне фізичне і духовне вдосконалення); свобода; творчість (можливість творчої діяльності); впевненість у собі. А також такі інструментальні цінності, як: вихованість (гарні манери); життєрадісність (почуття гумору); незалежність (здатність діяти самостійно, рішуче); освіченість (широта знань, високий рівень загальної культури); раціоналізм (уміння логічно мислити, приймати помірковані, раціональні рішення); самоконтроль (стриманість, самодисципліна); сміливість у відстоюванні своєї позиції, поглядів, думок; терпимість (до поглядів і думок інших, уміння прощати іншим їх помилки); широта поглядів (уміння зрозуміти іншу точку зору, поважати інші смаки, звички, звичаї).

Вибір аналізувався таким чином. Якщо перелічені цінності респондент оцінював балами від 1 до 6 включно - ми вважали їх найбільш значущими для респондента. Такі цінності ми називаємо цінностями першого рівня. Від 7 до 12 балів - цінності другого рівня. Від 13 до 18 - найменш значущі для респондента - цінності третього рівня. Ранжування показало, що найважливішою для респондентів серед термінальних цінностей є життєва мудрість, яка передбачає зрілість суджень та здоровий глузд як результат життєвого досвіду. Ї̈̈ відмітили 96 осіб (34,78\%) з 276. Далі за значенням ідуть впевненість у собі як цінність особистості. Можемо зробити висновок, що внутрішня гармонія, свобода від внутрішніх протиріч і сумнівів має неабияке значення для респондентів. Ця цінність є важливою для 78 респондентів (28,26\%). І третя за значенням цінність - свобода, яка виявляється у самостійності, незалежності в судженнях та вчинках. Вважаємо, що ця цінність є характерною для людей цього віку (22-24 роки). Ї̈̈ відмітили 72 особи, що становить 26,08\%. Показовим $€$ те, що творчість і краса природи та мистецтва обрали лише 24 (8,69\%) і 18 (6,52\%) респондентів відповідно. Мистецтво є образним осмисленням дійсності і є своєрідним провідником людини до культури. Тому вважаємо ці цінності не менш значущими для особистості, яка прагне досягти рівня людини культури.

Значення термінальних цінностей для респондентів представлено на рисунку 1 в порядку зменшення.

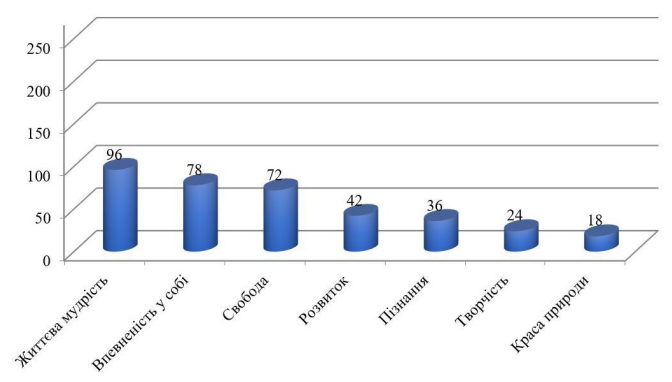

\section{Рис. 1. Значення термінальних цінностей для респондентів}

Щодо результатів розподілу респондентами інструментальних цінностей зазначимо, що вихованість визначили найвищою серед усіх цінностей. Ї̈̈ відзначили 240 респондентів (86,95\%). Більше половини респондентів надають важливого значення таким цінностям, як життєрадісність та освіченість. Ці цінності відзначили відповідно 168 $(60,86 \%)$ і $156(56,52 \%)$ респондентів. Всі інші цінності мають значно нижчий показник.

Узагальнено значення інструментальних цінностей для респондентів показано на рисунку 2 в порядку зменшення.

Далі, на основі даних про цінності першого рівня, як найбільш значущі для респондента, ми визначали рівень ціннісних орієнтацій майбутнього викладача. Високий рівень ціннісних орієнтацій присвоюється респонденту, в якого налічується від 9 до 12 цінностей першого рівня. Середній рівень ціннісних орієнтацій присвоюється респонденту, в якого налічується від 5 до 8 цінностей першого рівня. Низький рівень ціннісних орієнтацій присвоюється респонденту, в якого налічується від 1 до 4 цінностей першого рівня. Таким чином, ми маємо можливість зробити якісний аналіз отриманих результатів і кількісний аналіз ціннісних орієнтацій майбутнього викладача. Дані про цінності першого рівня дали можливість визначити рівень ціннісних орієнтацій майбутнього викладача (див. рисунок 3). 


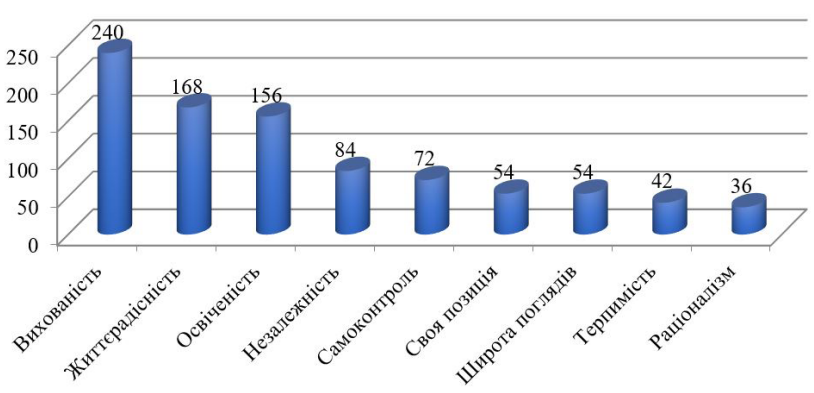

Рис. 2. Значення інструментальних цінностей для респондентів

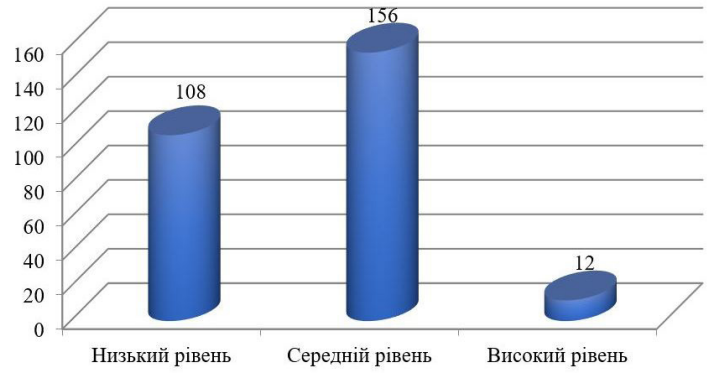

Рис. 3. Рівні ціннісних орієнтацій майбутнього викладача

Як бачимо, високий рівень ціннісних орієнтацій спостерігається лише у 12 респондентів (4,34\%). Ці респонденти обрали від 9 до 12 цінностей першого рівня. Середній рівень ціннісний орієнтацій властивий більшій частині респондентів. А саме: 156 осіб (56,52\%) відзначили від 5 до 8 цінностей першого рівня. Низький рівень ціннісних орієнтацій присвоєно 108 респондентам (39,13\%). Вони відзначили від 1 до 4 цінностей першого рівня. Отже, з 276 респондентів більшість мають середній рівень ціннісних орієнтацій.

Аналіз отриманих даних засвідчив необхідність у формуванні таких термінальних цінностей, як: пізнання, яке дає можливість розширення свого кругозору, загального рівня культури, підвищує рівень освіченості та інтелектуального розвитку; розвиток, у значенні роботи над собою, постійного духовного вдосконалення. А також таких інструментальних цінностей, як: терпимість до поглядів і думок інших, уміння прощати іншим їх помилки; широта поглядів (уміння зрозуміти іншу точку зору, поважати інші смаки, звички, звичаї); освіченість (широта знань, високий рівень загальної культури) та раціоналізм (уміння логічно мислити, приймати помірковані, раціональні рішення).

Формування полікультурної компетентності в цілому і ціннісних орієнтацій зокрема здійснювалось упродовж чотирьох етапів: несвідомої полікультурної некомпетентності, метою якого було усвідомити власну полікультурну некомпетентність; свідомої полікультурної некомпетентності - етап спрямований на формування у майбутнього викладача закладу вищої освіти потреби в полікультурній освіті; свідомої полікультурної компетентності, мета якого - оволодіння майбутнім викладачем закладу вищої педагогічної освіти теоретичними знаннями з питань полікультурної освіти; несвідомої полікультурної компетентності - спрямований на практичне оволодіння уміннями і навичками полікультурної компетентності. Для кожного етапу визначено мету і завдання, запропоновано зміст реалізації етапу, обрано форми і методи.

У результаті формування полікультурної компетентності відбулися зміни у ранжуванні ціннісних орієнтацій. Кількість осіб, які обрали вищеназвані цінності значно зросла. Відповідно змінився і рівень ціннісних орієнтацій майбутнього викладача, який визначався на основі цінностей першого рівня (див. таблицю 1).

Зокрема, до початку формувального експерименту низький рівень ціннісних орієнтацій спостерігався у 49 осіб (35,50\%), в експериментальній - у 59 осіб (42,75\%). Після формувального експерименту в контрольній групі кількість осіб з низьким рівнем зменшилась до 46 осіб (33,33\%), тоді як в експериментальній групі зменшилась до 31 особи (22,46\%). Кількість респондентів з середнім рівнем ціннісних орієнтацій в контрольній групі практично не змінилася, збільшилася всього на 3 особи: з 84 осіб (60,86\%) до 87 осіб (63,04\%), на відміну від експериментальної групи, де кількість респондентів з середнім рівнем збільшилася на 19 осіб (було - 72 особи (52,17\%), стало - 91 особа (65,94\%)). Щодо високого рівня, то в контрольній групі змін не відбулося, а в експериментальній кількість збільшилась 37 осіб (5,07\%) до 16 осіб (11,59\%). Таким чином, в експериментальній групі бачимо позитивні зміни у ціннісних орієнтаціях майбутніх викладачів.

Таблиця 1

Результати співвідношення рівня ціннісних орієнтацій після формувального експерименту

\begin{tabular}{|c|c|c|c|c|c|c|c|c|c|}
\hline \multirow{2}{*}{ № $\Pi / \Pi$} & \multirow{2}{*}{$\begin{array}{c}\text { Рівень } \\
\text { ціннісних } \\
\text { орієнтацій }\end{array}$} & \multicolumn{2}{|c|}{$\begin{array}{c}\text { КГ до } \\
\text { експерименту }\end{array}$} & \multicolumn{2}{|c|}{ ЕГ до експерименту } & \multicolumn{2}{|c|}{$\begin{array}{c}\text { КГ після } \\
\text { експерименту }\end{array}$} & \multicolumn{2}{|c|}{$\begin{array}{c}\text { ЕГ після } \\
\text { експерименту }\end{array}$} \\
\hline & & К-сть & $\%$ & К-сть & $\%$ & К-сть & $\%$ & К-сть & $\%$ \\
\hline 1. & Високий & 5 & 3,62 & 7 & 5,07 & 5 & 3,62 & 16 & 11,59 \\
\hline 2. & Середній & 84 & 60,86 & 72 & 52,17 & 87 & 63,04 & 91 & 65,94 \\
\hline 3. & Низький & 49 & 35,50 & 59 & 42,75 & 46 & 33,33 & 31 & 22,46 \\
\hline \multicolumn{2}{|c|}{ Всього: } & 138 & $100 \%$ & 138 & $100 \%$ & 138 & $100 \%$ & 138 & $100 \%$ \\
\hline
\end{tabular}




\section{ВИСНОВКИ ТА ПЕРСПЕКТИВИ ПОДАЛЬШИХ ДОСЛІДЖЕНЬ}

у дослідженні проблеми полікультурної освіти застосування аксіологічного підходу необхідне тому, що викладач $€$ особистістю зі сформованою системою цінностей, якою він керується у своїх соціальних та професійних взаємодіях. Система цінностей викладача визначає характер і спрямованість взаємодії в умовах освітнього процесу та виражається у здатності вільно орієнтуватися в складних соціальних і професійних ситуаціях, вибирати, здійснювати інноваційні процеси. Здійснений якісний і кількісний аналіз системи ціннісних орієнтацій майбутнього викладача до і після реалізації чотирьох етапів формування полікультурної компетентності засвідчив ефективність розробленого та запропонованого нами змісту полікультурної освіти.

\section{СПИСОК ВИКОРИСТАНИХ ДЖЕРЕЛ}

Андрущенко, В. (2013). Інтеграція цінностей: педагогічний досвід Європи. Стаття перша. Велика Хартія Університетів. Вища освіта України, № 1, С. 5-10.

Баранівський, В. (2014). Ціннісні орієнтації студентської молоді та їх роль в консолідації українського суспільства. Вісник ХНПУ імені Г.С. Сковороди «Філософія», Вип. 43, С. 39-52.

Барановська, Л. (2017). Вплив освітнього середовища ВНЗ на якість підготовки майбутніх фахівців. Розвиток сучасної освіти: теорія, практика, інновації, С. 38.

Леонтьев, Д. (1998). Ценностные представления в индивидуальном и групповом сознании: виды, детерминанты и изменения во времени. Психологическое обозрение, 1, С. 13-25.

Новейший философский словарь (1998). Мн.: Изд. В.М. Скакун.

Онофрійчук, Л. (2011). Аналіз рівня сформованості ціннісних орієнтацій студентів природничих спеціальностей педагогічного університету. Гуманізація навчально-виховного процесу, Вип. LVIII, Ч. II, C. 73-76.

Печерська, Г. (2013). Професійні ціннісні орієнтації вчителі. Збірник наукових праць. Психологічні науки, Том 2, Випуск 10 (91), С. 252-257.

Тюрина, В., Научитель, Е. (1998). Ценностные ориентации: учебное пособие. Киев: ООО «Международное фин. агентство».

Удич, О. (2014). Ціннісні орієнтації: багатогранність наукових трактувань. Рідна школа, № 11 (листопад), С. 26-31.

Хомич, Л. (2010) (Ред.). Аксіологічний підхід - основа формування цілісної особистості майбутнього педагога: монографія. Київ-Ніжин: Видавець ПП Лисенко ММ, 143 с.

Хомич, Л. (2014). Аксіологічні основи змісту навчання і виховання майбутніх вчителів. Педагогіка вищої школи: методологія, теорія, технології, 2 (Т. 1), С. 89-93.

Щепова, Д. (2010). Ціннісні орієнтації сучасного українського студентства. Вісник Запорізького національного університету. Педагогічні науки, № 2 (13), С. 181-184.

\section{REFERENCES}

Andrushchenko, V. (2013). Intehratsiia tsinnostei: pedahohichnyi dosvid Yevropy. Stattia persha. Velyka Khartiia Universytetiv. Vyshcha osvita Ukrainy, № 1, s. 5-10.

Baranivskyi, V. (2014). Tsinnisni oriientatsii studentskoi molodi ta yikh rol v konsolidatsii ukrainskoho suspilstva. Visnyk KhNPU imeni H.S. Skovorody «Filosofiia», Vyp. 43, s. 39-52.

Baranovska, L. (2017). Vplyv osvitnoho seredovyshcha VNZ na yakist pidhotovky maibutnikh fakhivtsiv. Rozvytok suchasnoi osvity: teoriia, praktyka, innovatsii, s. 38.

Leontev, D. (1998). Tsennostnыe predstavlenyia v yndyvydualnom y hruppovom soznanyy: vydы, determynantb y yzmenenyia vo vremeny. Psykholohycheskoe obozrenye, 1, s. 13-25.

Noveishyi fylosofskyi slovar (1998). Mn.: Yzd. V.M. Skakun.

Onofriichuk, L. (2011). Analiz rivnia sformovanosti tsinnisnykh oriientatsii studentiv pryrodnychykh spetsialnostei pedahohichnoho universytetu. Humanizatsiia navchalno-vykhovnoho protsesu, Vyp. LVIII, Ch. II, s. 73-76.

Pecherska, H. (2013). Profesiini tsinnisni oriientatsii vchyteli. Zbirnyk naukovykh prats. Psykholohichni nauky, Tom 2, Vypusk 10 (91), s. $252-257$.

Tiuryna, V., Nauchytel, E. (1998). Tsennostnue oryentatsyy: uchebnoe posobye. Kyev: OOO «Mezhdunarodnoe fyn. ahentstvo».

Udych, O. (2014). Tsinnisni oriientatsii: bahatohrannist naukovykh traktuvan. Ridna shkola, № 11 (lystopad), s. 26-31.

Khomych, L. (2010) (Red.). Aksiolohichnyi pidkhid - osnova formuvannia tsilisnoi osobystosti maibutnoho pedahoha: monohrafiia. Kyiv-Nizhyn: Vydavets PP Lysenko MM, $143 \mathrm{~s}$.

Khomych, L. (2014). Aksiolohichni osnovy zmistu navchannia i vykhovannia maibutnikh vchyteliv. Pedahohika vyshchoi shkoly: metodolohiia, teoriia, tekhnolohii, 2 (T. 1), s. 89-93.

Shchepova, D. (2010). Tsinnisni oriientatsii suchasnoho ukrainskoho studentstva. Visnyk Zaporizkoho natsionalnoho universytetu. Pedahohichni nauky, № 2 (13), s. 181-184. 